\title{
THE PROSECUTOR'S CONSTITUTIONAL DUTY TO REVEAL EVIDENCE TO THE DEFENDANT
}

PRESSURe for reform in the area of criminal discovery has led to an increasing literature on the subject. However, commentators have made only passing reference to a series of fourteenth amendment cases involving the suppression of evidence by the prosecutor and his duty to reveal that evidence to the defense. ${ }^{1}$ While none of the suppression cases talks about discovery explicitly the constitutional basis for these decisions might illuminate the constitutional status of discovery claims.

The most recent suppression cases ${ }^{2}$ seem willing to impose an extremely strict duty of disclosure on the prosecutor. To understand the modern cases it is important to know how the duty developed. The evolution began with Mooney v. Holohan. ${ }^{3}$ On July 22, 1916, a bomb exploded in the midst of a crowd which had gathered to watch the San Francisco Preparedness Day Parade. Tom Mooney, labor radical, agitator, and accused anarchist, was convicted of the crime and sentenced to death. Mooney claimed that the prosecutor fabricated the entire case. Subsequent investigation showed that every one of the state's witnesses had lied, with the encouragement of the district attorney and his assistants. ${ }^{4}$ The state's chief witness was probably at least ninety miles away at the time of the explosion. The district attorncy intentionally suppressed evidence concerning the credibility of every witness. ${ }^{\circ}$ And he suppressed a photograph showing Mooney and his friends on top of a distant building two minutes before the explosion.7

1. Traynor, Ground Lost and Found in Criminal Discovery, 39 N.Y.U.L. Rev. 228, 242-43 (1964); Garber, The Growth of Criminal Discovery, 1 Crin. L.Q. 3, 11-12 (1962) ; Goldstein, The State and the Accused: Balance of Advance in Criminal Procedure, 69 YALE L.J. 1149, 1182 n.108 (1960). No mention of the cases is made in Brentian, The Criminal Prosecution: Sporting Event or Quest For Truth, 1963 WASm. U.L.Q. 279; in Datz, Discovery in Criminal Procedure, 16 U. FLA. L. REv. 163 (1963); or in Note, 50 VA. L. REv. 535, 552-55 (1964), which argues for discovery as a constitutional right. Similarly, articles on these prosecutor's duty cases have made only casual suggestions regarding their implications for discovery. Note, 77 HAnv. L. Rev. 1528, 1530 (1964) ; Note, 39 N.Y.U.I. REv. 565, 570-71 (1964). See also Note, 60 ColuMr. L. Rev. 858 (1960).

2. United States ex rel. Butler v. Maroney, 319 F.2d 622 (3d Cir. 1963); Ashley v. Texas, 319 F.2d 80 (5th Cir. 1963).

3. 294 U.S. 103 (1935). The best account of the Mooncy case is contained in a report prepared by Zechariah Chafee, Jr., Walter H. Pollak, Carl S. Stern, and Thomas A. Halleran for the National Commission on Law Observance and Enforcement (The Wickersham Commission). Chafee, et az., The Mooney-Billings Report (1931).

4. $I d$. at $185-86$.

5. Id. at 133 .

6. Id. at $189-93$.

7. Id. at 187-89. The details of the "frame-up" are too complex to repeat. Howcver, THE MOONEY-BILlings RePort concluded, inter alia :

(5) Witnesses were produced at the trials with information in the hands of the prosecution that seriously challenged the credibility of the witnesses, but this information was deliberately concealed. 
The Supreme Court had little difficulty finding that Mooney's claim had constitutional dimensions. In a per curiam opinion the Court said that due process

is a requirement that cannot be deemed to be satisfied by mere notice and hearing if a State has contrived a conviction through the pretense of a trial which in truth is but used as a means of depriving a defendant of liberty through a deliberate deception of court and jury by the presentation of testimony known to be perjured. Such a contrivance by a State to procure the conviction and imprisonment of a defendant is inconsistent with the rudimentary demands of justice as is the obtaining of a like result by intimidation. ${ }^{8}$

In its opinion the Court emphasized the knowing use of perjured evidence because it was considered the most serious of the clains. No significance should be placed on its failure to mention the suppression of evidence favorable to the defendant. The suppression was as much a part of the "deliberate deception" as the use of perjured evidence. Pylc 2 . Kansas ${ }^{0}$ cleared away any doubt that existed.

Petitioner's papers ... . set forth allegations that his imprisonment resulted from perjured testimony knowingly used by the State authorities to obtain his conviction and from the delibcrate suppression by those same authorities of evidence favorable to him. These allegations sufficiently charge a deprivation of rights guaranteed by the Federal Constitution ....10

Although the line of cases generated by Mooncy involved both kinds of misconduct by the prosecutor the perjury isste is considered first because it provides a convenient background against which the recent development in the suppression doctrine can be viewed.

The earlier cases concerned with the knowing use of perjured cvidence merely affirmed the Mooney principle. ${ }^{11}$ Recent cases show that neither the effect of the perjury on the jury nor the extent of the prosecutor's instigation

(6) Witnesses were permitted to testify at the trials, despite such knowledge in the possession of the prosecution of prior contradictory stories told by these witnesses, as to make their mere production a vouching for perjured tectimony.

(7) Witnesses were coached in their testimony to a degree that approximated subornation of perjury. There is a strong inference that some of this cosching was done by prosecuting officials, and other evidence points to knowledge by the prosecuting officials that such coaching was being practiced by other witnesses.

(9) After the trials, the disclosures casting doubt on the justice of the convictions were minimized, and every attempt made to defeat the liberation of the defendants, by a campaign of misrepresentation and propaganda carried on by the officials who had prosecuted them.

Id. at $242-43$.

8. 294 U.S. 103, 112 (1935). The writ did not issue, though, because Mooney had not exhausted his state remedies. Id. at 113-15.

9. 317 U.S. 213 (1942).

10. "Id. at 215-16 (emphasis added).

11. See Pyle v. Kansas, 317 U.S. 213 (1942); and White v. Ragen, 324 U.S. 760 (1945). 
need go as far as in Mooney. In Alcorta v. Texas ${ }^{12}$ the Court found a denial of due process even though the prosecutor did not instigate the perjury and even though the perjury was relevant only to Alcorta's sentence, not to his guilt. In Napue v. Illinois ${ }^{13}$ the Court held that a lie which did not concern any of the facts of the case, but involved the credibility of the witness, tainted the conviction and necessitated a new trial.

Alcorta and Napue extended the prosecutor's duty regarding perjured evidence, but not radically. Fundamentally that duty is not to suborn perjury, ${ }^{14}$ not to use evidence known to be false, ${ }^{15}$ and to correct state witnesses who lie. ${ }^{16}$ Each of these duties provides protection for the individual defendant. While that protection may provide the due process basis for the perjury cases there is another constitutional consideration.

Perjury or the possibility of perjury strikes at the heart of the judicial system in its role as finder of truth. When the prosecutor involves himself in perjury he lends official sanction to the fraud. Necessarily the court, also a representative of the state, becomes linked with the prosecutor. The court must combat this threat to its own dignity and to the dignity of the criminal system or risk the possibility that the community will lose faith in the entire criminal process. Thus these cases provide protection for the court and the legal system as well as for the defendant.

Because the prosecutor's misconduct threatens an interest in addition to that of the individual defendant the perjury cases sometimes look more to the prosecutor's actions than to the defendant's harm. This is true even though the courts usually talk in terms of constitutional principles based on prejudice to the defendant. For example, in Napue v. Illinois ${ }^{17}$ the Supreme Court said that because the witness' lie bore on his credibility the petitioner was prejudiced. In that case the witness testified that nobody had promised him consideration for his testimony when in fact the assistant district attorney had. However, subsequent testimony apprised the jury of his lie. On cross examination the witness admitted that some unidentified lawyer had promised him consideration. ${ }^{18}$ The Court stressed that the jury never knew the prosecutor did the promising. But the jury did know the witness lied, which was the only relevant fact in determining the witness' credibility. In short, the Court did not explain how this particular lie prejudiced the defendant. Nonetheless it held that there had been a denial of due process. The only explanation is that the Court concerned itself with the prosecutor's conduct more than with the defendant's harm, with a protection of the criminal process

12. 355 U.S. 28 (1957).

13. 360 U.S. 264 (1959).

14. Mooney v. Holohan, 294 U.S. 103 (1935).

15. Alcorta v. Texas, 355 U.S. 28 (1957).

16. Napue v. Illinois, 360 U.S. 264 (1959).

17. Ibid.

18. Id. at 268 . 
rather than with the possibility that the lie influenced the defendant's conviction. ${ }^{19}$

In the early years the suppression doctrine relied on the same rationale as the perjury doctrine. A fraud by the prosecutor threatens the integrity of the criminal system. For example, in United States cx rel. Montgomery v. Ragen ${ }^{20}$ petitioner was convicted of rape. Before the trial the prosecutor received a hospital report which indicated that no rape had been committed on the alleged victim. The examining doctor told the prosecutor he found no evidence of rape. The prosecutor suppressed both the oral and written reports. As in the Mooney case the court was faced with a "frame-up." The suppressed evidence would have exonerated petitioner completely. "There

19. A similar case, upon which the Supreme Court relied in Napue, articulated the concern more clearly.

The administration of justice must not only be above reproach, it must also be beyond the suspicion of reproach ..... It is of no consequence that the falschood bore upon the witness' credibility rather than directly upon defendant's guilt. A lie is a lie, no matter what its subject, and, if it is in any way relevant to the case, the district attorney has the responsibility and duty to correct what he lnows to be false and elicit the truth. Nor does it avail [the State] ... to contend that defendant's guilt was clearly established or that disclosure would not have changed the verdict. ... We may not close our eyes to what occurred; regardless of the quantum of guilt or the asserted persuasiveness of the evidence, the episode may not be overlooked.

People v. Savvides, 1 N.Y.2d 554, 556-57, 136 N.E.2d 853, 854, 154 N.Y.S.2d 885, 887 (1956). See also Judge Magruder concurring in Coggins v. O'Brien, 188 F.2d 130, 139 (1st Cir. 1951).

The cases denying relief to defendants convicted by a lie not known to the prosecutor provide another indication that the perjury cases protect more than only the interests of the defendant. If only the defendant's interests were at stake the fact that the prosecutor acted innocently would have no importance since the defendant is harmed as much in these cases as in the knowing use cases. See United States ex rel. Wilson v. Pate, 332 F.2d 886 (7th Cir. 1964) ; Green v. United States, 313 F.2d 6 (1st Cir. 1963) ; Harrison v. Boles, 307 F.2d 928 (4th Cir. 1962); United States v. Jakalski, 237 F.2d 503 (7th Cir. 1956); Wild v. Oklahoma, 187 F.2d 409 (10th Cir. 1951); Hinley v. Burford, 183 F.2d 581 (10th Cir. 1950) ; Rollins v. Boles, 228 F. Supp. 6 (N.D. W. Va. 1964).

For the minority view, see Jones v. Kentucky, 97 F.2d 335 (6th Cir. 193S); United States ex rel. Miller v. Pate, 226 F. Supp. 541 (N.D. Ill. 1963); Durley v. Mfayo, 351 U.S. 277, 290-91 (1956) (Douglas, J. dissenting, joined by Warren, Black, and Clark, J.J.) :

It is well settled that to obtain a conviction by the use of testimony known by the prosecution to be perjured offends due process. [Citations omitted] While the petitioner did not allege that the prosecution knew that petitioner's codefendants were lying when they implicated petitioner, the State now knows that the testimony of the only witnesses against petitioner was false No competent evidence remains to support the conviction. Deprivation of a hearing under these circumstances amounts in my opinion to a denial of due process of law.

Ibid. See generally Cahn, Law in the Consumer Perspective, 112 U. PA. L. Rxv. 1, 7-12 (1963).

20. 86 F. Supp. 382 (N.D. Ill. 1949). 
was no trial here, but a sham, one of false pretenses and fraud."21 The Supreme Court concluded that

The methods employed by the prosecution ... represents as shocking a situation as ever before presented before this Court. A society cannot suppress lawlessness by an accused through the means of lawlessness of the prosecution. A society cannot inspire respect for the law by withholding its protection from those accused of crimes. ${ }^{22}$

The theory of the suppression cases did not remain static. In United States ex rel. Almeida $v$. Baldi ${ }^{23}$ petitioner was convicted of first degrec murder for killing a police officer during the course of a robbery. He was sentenced to death. The state did not reveal the existence of a bullet which indicated that the defendant was not the actual killer. Because the state prosecuted on a felony-murder theory the bullet had no relevance to the guilt or innocence of the accused. The prosecutor did not manufacture the case. Yet proof that the petitioner did not actually fire the shot that killed the policeman might have mitigated the sentence. The Third Circuit held that the suppression denied petitioner due process. Although the statement of the court was unclear the decision indicated that it was not necessary to prove the kind of fraud found in Mooney or Montgomery.

United States ex rel. Thompson v. Dye ${ }^{24}$ extended Almeida significantly. Thompson was convicted of first degree murder and sentenced to death. His defense was that he was too drunk at the time of the crime to formulate the necessary intent for first degree murder, or alternatively that his drunken

21. Id. at 387.

22. Ibid. In White Thunder v. Hunter, 149 F.2d 578 (10th Cir. 1945), the Tenth Circuit did not find the requisite fraud and did not issue the writ, even though the suppressed evidence would have helped the defendant. Before his trial White Thunder could not remember where he was on the night of the alleged rape. His mother remembered that he was at home because that was the night his sister, Charlotte Thin Elk, came home from the hospital. But his wife claimed that he was in Nebraska visiting her family. In order to resolve his doubts petitioner requested that the district attorney subpocna two more witnesses, his sister and one Elmer Jones, a mechanic in White Thunder's garage. The district attorney never issued the subpoena. When the witnesses did not appear, White Thunder accepted his mother's version of the story. After she testified at the trial the district attorney impeached her testimony by producing hospital records showing that Charlotte Thin Elk was not released until the night after the crime.

At the subsequent habeas corpus hearing White Thunder's mother-in-law testificd that he had been at her home in Nebraska on the night of the crime, and that Elmer Joncs, one of the missing witnesses, would have verified the story. Therefore it is impossible to agree with the court that the suppressed evidence would have been "unavailing." Certainly if Jones had testified that White Thunder was in Nebraska at the time of the crime tho state could not have destroyed this alibi by producing the hospital records. The only way to understand the denial of habeas corpus is by asstuming that while there was a suppression of evidence which would have been favorable to the defense, the court would allow the claim only if a fraud or "frame-up" could be proven.

See also Woollomes v. Heinze, 198 F.2d 577, 579 (9th Cir. 1952).

23. 195 F.2d 815 (3d Cir. 1952).

24. 221 F.2d 763 (3d Cir. 1955). 
state should mitigate the sentence. He presented his own testimony and the testimony of another to prove he was drunk, but the jury did not believe them. One of the arresting officers would have supported the story by testifying that at the arrest, four hours after the murder, Thompson appeared drunk. The prosecutor suppressed this evidence. Nothing in the opinion indicates that the prosecutor intended to "frame" the defendant. It is perfeatly conceivable that the District Attorney believed the arresting officer wrong. Other equally believable witnesses testified that the defendant was "perfectly alright."25 Yet the Third Circuit held the failure to reveal the arresting officer's testimony a denial of due process.

Thompson gave a new direction to the suppression cases. For the first time the prosecutor's motive might have been completely innocent. Because the prosecutor might not have committed a fraud the rationale based on the protection of the criminal system disappears. The primary interest at stake is the defendant's. Although unstated this change was suggested by the emphasis the Third Circuit placed on exactly how the suppressed evidence might have helped the defendant. After Thompson the suppressed evidence cases could be based, in some as yet undefined way, solely on the disadvantage to the defendant.

Two Second Circuit cases made explicit what Thompson suggested, that courts need not concern themselves primarily with the prosecutor's motives and instead can concentrate on the defendant's harm. In United States $v$. Consolidated Laundries Corp. ${ }^{26}$ a negligent suppression of evidence by the prosecutor necessitated a new trial. As in Thompson a major emphasis was placed on how the evidence might have helped defendants. Again in $K y / e$ 21. United States ${ }^{27}$ the Second Circuit held that even a negligent suppression of evidence could require a new trial depending on how much the suppression harmed the defendant. ${ }^{28}$

25. Id. at 765 .

26. 291 F.2d 563 (2d Cir. 1961).

27. 297 F.2d 507 (2d Cir. 1961).

28. In his opinion Judge Friendly attempted to formulate a relationship between the degree of misconduct and the degree of harm necessary for a new trial:

[T] he standard of how serious the probable effect of an act or omission at a criminal trial must be in order to obtain the reversal or, where other requirements are met, the vacating of a sentence, is in some degree a function of the gravity of the act or omission; the strictness of the application of the harmless error standard scems somewhat to vary, and its reciprocal, the required showing of prejudice, to vary inversely, with the degree to which the conduct of the trial has violated basic concepts of fair play. At one end of the range is the case where the defendant has simply. although excusably, not had the benefit of evidence that has later become available to him; there the Berry test [Berry v. State, $10 \mathrm{Ga} .511$ (1851)], requires a showing that the new evidence "would probably produce a different verdict." At the other end of the range is the case of a defendant being obliged to plead to a capital charge without benefit of counsel; there the court "does not stop to inquire whether prejudice resulted." Hamilton v. State of Alabama, 82 S. Ct. 157, 159 (1961).

297 F.2d at 514. See also Note, 60 CoLuns. L. Rev. 858, 864-65 (1960). 
Because Kyle and Consolidated Laundries involved Federal prosecutions neither opinion depended on the fourteenth amendment. However, both greatly affected later fourteenth amendment cases. In 1962 two cases involving state prosecutions explicitly adopted the Kyle theory that the prosecutor's motive does not determine the case. In Smallwood $v$. Warden ${ }^{20}$ the state's attorney withheld evidence concerning both the physical condition and the reputation of an alleged rape victim. The court accepted the prosecutor's testimony that he acted in good faith but said that "his motive is immaterial if the evidence was vital, i.e. was likely to have affected the result of the trial," citing Kyle and Thompson..$^{30}$ In Application of Kapatos ${ }^{81}$ the prosecutor failed to reveal that an eyewitness to the murder in question would have refused to identify the defendant. Judge Palmieri granted the petition for a writ of habeas corpus explicitly adopting the Kyle reasoning. ${ }^{32}$

Finally, in 1963 the Supreme Court approved these developments. In Brady v. Maryland ${ }^{33}$ petitioner was convicted of first degree murder on a felonymurder theory. He admitted his guilt but asked for leniency. His lawyer asked the state's attorney for a companion's confession to prove that the companion rather than the appellant did the actual killing. The state turned over all the companion's statements except the one in which he admitted the actual homicide. The Maryland Court of Appeals granted a new trial on the issue of sentencing only. On appeal the Supreme Court went out of its way to affirm the principle of the Maryland decision.

We now hold that the suppression by the prosecution of evidence favorable to an accused upon request violates due process where the evidence is material either to guilt or to punishment, irrespective of the good faith or bad faith of the prosecution.84

According to Brady courts need no longer focus upon the conduct of the prosecutor. When courts do not concern themselves with the prosecutor's misconduct the constitutional rationale based on fraud has no application. Instead Brady focuses upon prejudice to the defendant. But prejudice alone cannot transform an objection into a constitutional claim. Some factor must differentiate this prejudice from the many constitutionally accepted ways defendants can be harmed. For example, an erroneous admission of evidence by a state trial court or a bad interpretation of a state law, without more, would not raise a constitutional issue, although both errors might harm the defendant.

The factor which differentiates the suppression cases and gives them constitutional dimension is that they grow out of a situation which makes a fair trial for many defendants nearly impossible. Suppressed evidence would not

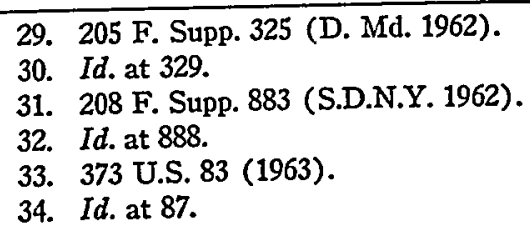


be a major problem if the defendant had facilities adequate to gather his own evidence before the trial. But the defendant's facilities are usually meager especially when compared to those of the state. ${ }^{35}$ It seems self-evident that if a defendant cannot obtain enough evidence to defend himself he cannot have a fair trial. ${ }^{36}$ When the prosecutor aggravates defendant's lack of ability to obtain evidence by not revealing to him material evidence the Constitution has been violated. ${ }^{37}$ Thus Brady embraces a concept of fairness with which

35. In most criminal cases, the prosecutor has tremendous advantages. In considering the economic and social facts of life, one cannot possibly compare the total discovery potential of the prosecution and the defense in any terms of equality.

Garber, supra note 1, at 5.

Fairly clearly, pretrial discovery by the prosecution is far reaching. And it cannot in any sense be said to be matched by what is available to the defendant or by what he can keep from the prosecutor - even when his immunity from self-incrimination is thrown into the scales. While the possibility that a hitherto undisclosed witness or theory of defense is always present, an opportunity for surprise is rendered practically illusory by the government's broad investigatory powers and by the requirement in many states that the defenses of alibi and insanity must be specifically pieaded. The sum of the matter is that the defendant is not an effective participant in the pretrial criminal process. It is to the trial alone that he must look for justice. Yot the imbalance of the pretrial period may prevent him from making the utmost of the critical trial date.

Goldstein, supra note 1, at 1192; Fletcher, Pretrial Discovery in State Criminal Cases, 12 Stan. L. Rev. 293, 305-06 (1960). See also Jonnt Cosrarttree on Contraunic Legnt Eddcation of the Axierican Law Instrtute and the Aurericar Bar Assoctation, Problears in Crtminal Law and Its Adartmistration, The Problear of A Crominial Defense 3-6 (1961) ; Report of the Attorney General's Cosnattree 0:i Poverty and the Adainnistration of Federal Criamnat Justice 26-29 (1963).

36. See Traynor, stipra note 1 , at 242.

37. In claiming for the suppression cases the constitutional principle that a defendant who can not obtain enough evidence to defend himself has not had a fair trial primary emphasis has been placed on an analysis of what the courts did in each case. However the language of the cases lends additional support to this theory.

The purpose of a trial is as much the acquittal of an innocent person as the conviction of a guilty one. The average accused usually does not have the manpower or resources available to the state in its investigation of the crime. Nor does he have access to all the evidence, much of which has usually been removed or obliterated by the time he learns that he is to be tried for the crime. In view of this disparity between the investigating powers of the state and the defendant, I do not thins: it imposes too onerous a burden on the state to require it to disclose the existence of a witness of the significance of Danise in the instant case.

Application of Kapatos, 208 F. Supp. 883, 888 (S.D.N.Y. 1962). See also United States ex rel. Meers v. Wilkins, 326 F.2d 135, 139-40 (2d Cir. 1964).

The principle of Mooney $v$. Holohan is not punishment of society for misdeeds of a prosecutor but avoidance of an unfair trial to the accused. Society wins not only when the guilty are convicted but when criminal trials are fair; our system of the administration of justice suffers when any accused is treated unfairly. . . . A prosecution that withholds evidence on demand of an accused which, if made available, would tend to exculpate him or reduce the penalty helps shape a trial which bears heavily on the defendant.

Brady v. Maryland, 373 U.S. 83, 88 (1963).

[W] state that the trial of a capital case, or indeed of any other trial, no longer can be considered properly a game of wits and skill. It is clear that men on trial for 
most courts $^{38}$ and commentators ${ }^{30}$ agree. ${ }^{40}$ The importance of Brady and the other suppression cases is not in any new principle they express but

their lives are entitled to all pertinent facts relating to their defense. . . . [C]ounsel for defendants were entitled to the facts and to make such use of the facts as they saw fit.

Curran v. Delaware, 259 F.2d 707, 711 (3d Cir. 1958).

38. Many courts have either affirmed or assumed the principle that if a defendant does not have enough evidence to defend himself he cannot have a fair trial.

In Jencks v. United States, 353 U.S. 657 (1957), the Supreme Court reversed a conviction because the trial court denied defendant's motion for an order requiring the prosecution to produce previously reported statements of one of the witnesses. The Court held that the defendant need not show conflict between the previous reports and the testimony. Requiring the accused first to show conflict between the reports and the testiniony is actually to deny the accused evidence relevant and material to his defense. . . . A requirement of a showing of conflict would be clearly incompatible with our standards for the administration of criminal justice in the federal courts and must therefore be rejected. ...

[T] he petitioner is entitled to inspect the reports to decide whether to use them in his defense. Because only the defense is adequately equipped to determine the effective use for purpose of discrediting the Government's witness and thereby furthering the accused's defense, the defense must initially be entitled to see them to determine what use may be made of them. Justice requires no less.

Id. at 667-69.

In Roviaro v. United States, 353 U.S. 53 (1957), the Supreme Court said:

A further limitation on the applicability of the [informer's] privilege [which would act to deny defendant information] arises from the fundamental requirements of fairness. Where the disclosure of an informer's identity, or of the contents of his communication, is relevant and helpful to the defense of an accused, or is essential to a fair determination of a cause, the privilege must give way.

Id. at 60-61.

See Palermo v. United States, 360 U.S. 343, 362-63 (1959); People v. Johnson, 356 Mich. 619, 626-28, 97 N.W.2d 739, 742-43 (1959) ; State v. Johnson, 28 N.J. 133, 137, 145 A.2d 313, 316 (1958); Powell v. Superior Court, 48 Cal. 2d 704, 705, 312 P.2d 698, 699. 700 (1956); People v. Riser, 47 Cal. 2d 566, 586, 305 P.2d 1, 13 (1956); State c.r rel. Mahoney v. Superior Court, 78 Ariz. 74, 79, 275 P.2d 887, 890 (1954); Commonwealth v. Stepper, 54 Lack. Jur. 205, 212 (Pa. C.P. 1952).

39. Do not these less privileged of our society present the particular problem that without resources to prepare a defense, they often don't have an adequate defense? Can we boast a decent administration of the criminal law if we don't provide them with some redress against hard reality?

Brennan, supra note 1 , at 286 . See Garber, supra note 1, at 12 ; Traynor, supra note 1 , at 242; Goldstein, supra note 1, at 1192, quoted in note 35 supra. See also Fletcher, supra note 35, at 305-08; and Krantz, Pretrial Discovery in Criminal Cases: $A$ Necessity For Fair and Impartial Justice, 42 NEB. L. REv. 127, 130-33 (1962).

40. Those who claim that trials are fair enough without giving the defendant any evidence argue that the defendant's privilege against self-incrimination and other protections adequately redress the imbalance caused by the state's overwhelming investigatory facilities، See, e.g., State v. Tune, 13 N.J. 203, 211-12, 98 A.2d 881, 884-85 (1953) ; State v. Rhoads, 81 Ohio St. 397, 425, 91 N.E. 186, 192 (1910); Flannery, The Prosecutor's Case Against Liberal Discovery, 33 F.R.D. 74 (1963). But these arguments ignore the defendant's real position. See Goldstein, supra note 1. See also note 35 supra; Lotisell, Criminal Discoutry: Dilemma Real or. Apparent?, 49 CALIF. L. Rev. 56, 86-90, 97 (1961). 
in their indication that the principle has constitutional dimensions and must be enforced in state proceedings.

Having recognized the prosecutor's constitutional duty to reveal evidence to the defendant the courts must now formulate standards to determine what kinds of evidence must be revealed. Some courts have attenpted to do so. For example, in Kyle v. United. States ${ }^{41}$ Judge Friendly measured the defendant's prejudice by how much the suppressed evidence affected the jury's verdict. Absent misbehavior by the prosecutor Friendly would require a showing that the suppressed evidence "would probably produce a different verdict." 2

But this formulation loses sight of what causes the defendant's prejudice. It is the imbalance of investigatory facilities which harms the defendant. The imbalance leads to an uninformed and poorly prepared defense, and consequently to an unfair trial. .3 $^{43}$ The real harm is done before the trial and it is to that period rather than to the trial and the highly speculative impact on the jury, that courts should look. If the question asked by the court is to correspond to the real needs of the defendant out of which these cases grew, and to the factor which gives these cases constitutional dimensions, it must be, what effect did the suppression have on defendant's preparation for trial?

Two recent cases illustrate that courts have begun to recognize this question as germane to the determination of whether the suppression of evidence denies defendants due process. In United States ex rel. Butler 21. Maroney th the petitioner had been convicted of murder in the first degree. Butler claimed that he was denied due process because the trial judge refused to allow his lawyer to examine a statement given to the police by an eye witness. The statement showed that the victim and petitioner had struggled before the shooting. Judge Ganey cited Brady and ordered the writ to be issued.

It seems clear that evidence contained in the statement would not have affected the jury's verdict. Since the jury already had adequate evidence before it concerning the struggle ${ }^{45}$ the suppressed evidence was cumulative only. The Butler case cannot be understood in terms of the prejudicial effect of the suppression in the eyes of the jury. As in the other cases the real injury was done to the defendant before the trial, when counsel was preparing his case. At the trial counsel based his entire defense on defendant's temporary insanity at the time of the shooting. Although facts indicating an accidental shooting came out at the trial counsel did not emphasize them. Had he seen the statement earlier he might have claimed an additional defense, and his

41. 297 F.2d 507 (2d Cir. 1961).

42. Id. at 514. See also Brady v. Maryland, 373 U.S. 83, 87 (1963); United States ex rel. Thompson v. Dye, 221 F.2d 763, 769 (3d Cir. 1955) (Hastie, J., concurring); Application of Kapatos, 208 F. Supp. 883, 888 (S.D.N.Y. 1962); Smallwood v. Warden, 205 F. Supp. 325, 329 (D. Md. 1962) ; Application of Landeros, 154 F. Supp. 183, 186-88 (D.N.J. 1957).

43. See notes $35-36$ supra and accompanying text.

44. 319 F.2d 622 (3d Cir. 1963).

45. See $i d$. at $629-31$ (Kalodner, J., dissenting). 
case might have been reorganized to emphasize the struggle. The defendant was injured because his counsel did not see the statement and therefore did not include a possible defense. ${ }^{46}$

A recent Fifth Circuit case contains a more explicit recognition of the question. In Ashley $v$. Texas ${ }^{47}$ the appellant was convicted of murder and sentenced to death. He claimed that he was denied due process by the stuppression of a report given to the prosecutor by two psychiatrists indicating that Ashley was insane. Instead the defense counsel was informed that another psychiatrist, Dr. Sher, found Ashley sane. In this case the suppressed infor* mation did not even relate to the only defense raised at trial - self defense. But it adversely affected the preparation for trial. Ashley's lawyer testified that Dr. Sher's report

led me to the conclusion that no other psychiatrist of any kind had examined the defendants or either of them, at the request of the District Attorney's office, and had I been informed of Dr. Crowe and Dr. Tracktir had made a finding that Leslie Douglas Ashley was of unsound mind and legally insane, as contemplated by the criminal laws of the State of Texas then, of course, I would have enlisted further psychiatric assistance in the case and sought to have the testimony of Dr. Crowe and Dr. Tracktir adduced before a jury on a defense of insanity as to said Leslie Douglas Ashley prior to the main trial, or as issues in the main trial, and in either event would have in all likelihood pleaded insanity as of the time of the insanity hearing and the main trial, and would not have introduced I.eslie Douglas Ashley as a witness in his own behalf in a joint trial of the two defendants. 48

Admirably, Judge Tuttle focused on defendant's pre-trial preparation and not on any supposed effect on the jury.

We conclude that without any such expression from the trial counsel that the fact of the opinions of Drs. Crowe and Tracktir favorable to the defendants, is of such vital significance to the accused persons in planning and conducting their defense, the failure of the District Attorney to inform their counsel of this fact amounts to such fundamental unfairness in the trial of a criminal case as to amount to a denial of due process..$^{40}$

If the courts accept the effect of the undisclosed evidence on defendant's preparation for trial as determining whether due process has been denied, and they cannot reject this standard without also rejecting the constitutional basis for the suppression cases, then the complete suppression of evidenze can no longer be the court's only concern. Any failure to reveal evidence before the trial may affect preparation adversely, even if the evidence is pre-

46. "This withholding by the Commonwealth of information impinging on a vital area in appellant's defense is a denial of the Due Process Clause of the 14th Amendment." Id. at 627.

47. 319 F.2d 80 (5th Cir. 1963). See Note, 77 Harv. L. Rev. 1528 (1964).

48. 319 F.2d at 85 .

49. Ibid. See also United States $e x$ rel. Meers v. Wilkins, 326 F.2d 135 (2d Cir. 1964). "We cannot speculate as to the effect this testimony would have had on the jury if it had an opportunity to hear it." Id. at 140. 
sented at trial. If the principle of the suppression cases is followed, the prosecutor's duty must expand significantly.

Previously that duty seems to have been limited to revealing evidence tending to prove the defendant innocent.50 But limiting the prosecutor's duty to exculpatory evidence does not meet the constitutional demands of the suppression cases. Unfavorable evidence may help the defendant prepare his case. A confession might be extremely damaging. But if the prosecutor does not reveal it the defendant may be substantially hampered in his preparation for trial, more seriously hampered, perhaps, than if the prosecutor had failed to reveal exculpatory evidence. ${ }^{51}$ Documents, papers and other tangible evidence might tend to prove defendant's guilt, but unless the prosecutor reveals them the defendant cannot prepare his case properly. ${ }^{\mathrm{I} 2}$

Another reason exists for not limiting the prosecutor's duty to exculpatory evidence. In many cases it is impossible to tell in advance of trial what evidence tends to prove innocence and what does not. Most evidence is inherently neutral. A used bullet proves no one guilty unless the prosecutor provides the necessary links between the defendant, the bullet and the victim. Similarly, the bullet proves no one innocent until the defense lawyer can show that there was no connection. Unless the bullet is revealed, though, the defendant's lawyer may never have the chance to show that it is exculpatory.

Neither can the evidence's admissibility circumscribe the duty. Certainly inadmissible evidence can help the defendant prepare his case as much as admissible evidence. Also, any judgment concerning admissibility made before the trial cannot be tested effectively unless the defense lawyer is given the opportunity to argue the issue. If the prosecutor makes the decision he will have performed his adversary's job. Griffin $v$. United States ${ }^{33}$ illustrates. There the prosecutor did not reveal that an open penknife had been found in the deceased's pocket. Since its existence was unknown to the appellant at the time of the murder, it would have been an "uncommunicated threat." At the time of the trial the uncommunicated threat theory of self-defense had not been accepted in the District of Columbia. The prosecutor thought that the evidence was not admissible because it was not relevant to any issue in the case. On appeal the circuit court changed the rule regarding uncommunicated threats and held that the suppression of the knife necessitated a new

50. Some courts talk about the duty in terms of exculpatory cvidence. E.g., Pyle v. Kansas, 317 U.S. 213, 216 (1942). Others talk about "material" evidence. E.g, United States ex rel. Thompson v. Dye, 221 F.2d 763, 765 (3d Cir. 1955). And some courts talkabout both in the same opinion. Compare Brady v. Maryland, 373 U.S. 83, 87 (1963), quoted in text accompanying note 34 supra, with Brady v. Maryland, id. at 88, quoted in note 37 supra. Although their language and reasoning may have lacked precision courts have given relief only when the evidence was exculpatory in some way.

51. See State v. Johnson, 28 N.J. 133, 145 A.2d 313 (1958).

52. See State ex rel. Mahoney v. Superior Court, 78 Ariz. 74, 275 P.2d 887 (1954).

53. 183 F.2d 990 (D.C. Cir. 1950). See also Pretryarar, Deatr and the Surreare COURT 107-36 (1961). 
trial. If the evidence had remained suppressed, the prosecutor's judgment that it was irrelevant could not have been challenged.

[The prosecutor's] opinion that evidence of the concealed knife was inadmissible was a reasonable opinion, which the District Court sustained and no court has overruled until today. However, the case emphasizes the necessity of disclosure by the prosecution of evidence that may reasonably be considered admissible and useful to the defense. When there is substantial room for doubt, the prosecutor is not to decide for the court what is admissible or for the defense what is useful. ${ }^{54}$

If the rationale of the suppression cases is to be followed the only acceptable standard is the evidence's usefulness to the defense. This standard requires the prosecutor to reveal all relevant evidence ${ }^{\text {t5 }}$ since the usefulness of any particular piece of evidence can be tested effectively only by revealing it to the defense. Allowing the prosecutor to judge whether or not evidence is helpful without giving it to the defense counsel would be tampering with the adversary process dramatically. The prosecutor's job is to present the state's case, not to determine what theories his opponent can use. The Griffin court recognized that "the prosecutor is not to decide ... for the defense what is useful." 56

Perhaps it would be possible to allow the judge to decide the usefulness of the evidence without first revealing it to the defense. ${ }^{\text {.7 }}$ In civil suits courts are forced sometimes to do just that.58 However, those cases are exceptional ones, usually involving claims of privilege by the party opposing disclosurc. The major effort has been to minimize judicial intervention. ${ }^{60}$ The same reasons for not involving the courts in civil cases apply in criminal ones. The administrative burden of deciding usefulness in every case would overbear the courts. Usually the judge does not know enough about the case at the time he must decide usefulness for that decision to be an informed one. In order to inform himself adequately he must try the entire case every time a question arises.

54. 183 F.2d at 992-93. In California a defendant need not show that evidence is admissible in order for it to be discoverable. People v. Cooper, 53 Cal. 2d 755, 770, 349 P.2d 964, 973 (1960) ; Traynor, stipra note 1, at 244 n.93.

55. The concept of revelance should be construed broadly, as in civil cases. Sec 4 Moore, Federal Practice 1174-85 (1963); Griffin v. United States, 183 F.2d 990, 993 (D.C. Cir. 1950).

56. 183 F.2d at 993 . See also Traynor, supra note 1, at 228:

The plea for the adversary system is that it elicits a reasonable approximation of the truth. The reasoning is that with each side on its mettle to present its own case and to challenge its opponent's, the relevant unprivileged evidence in the muin emerges in the ensuing clash. Such reasoning is hardly realistic unless the evidence is accessible in advance to the adversaries so that each can prepare accordingly in the light of such evidence.

57. See Application of Kapatos, supra note 31, at 888.

58. See, e.g., United States v. Reynolds, 345 U.S. 1, 11 (1953), where the Court decided that the evidence involved was not very necessary since an alternative source of evidence existed.

59. 4 Moore, Federal Practice 1040-42 (1963). 
Even absent administrative considerations there is no assurance that courts could make this determination successfully. The judge's decision will be no more than a guess. What weight will he give to the ingenuity of the defense counsel? In short, judges are unsuited to answer particular questions of usefulness. These questions should be for the accused's lawyer. ${ }^{\circ}$ The judge's job is as a neutral arbiter, not as a defense strategist. ${ }^{61}$

Unless the courts repudiate the constitutional basis of the suppression cases, and thereby reject the thirty-year development of a principle now widely accepted, ${ }^{62}$ the prosecutor should be required to reveal all relevant evidence to the defendant. Many serious questions concerning how the duty will be enforced remain for the courts to answer. For example, it seems inconceivable that the courts will continue to wait for an appeal or a habeas corpus hearing to impose the duty. Since all the evidence will be revealed eventually ${ }^{c s}$ and a new trial granted, it seems irrational to wait so long before requiring the disclosure. Similarly to impose the duty during the trial would require constant continuances ${ }^{64}$ and therefore would not be administratively feasible. The only reasonable time for the prosecutor to reveal his evidence is during the pretrial period. ${ }^{65}$ Questions concerning whether or not defense counsel must request the evidence also remain to be answered. ${ }^{00}$ Ways of protecting the legitimate interests of the prosecutor - informer's privilege, work-product protection, protecting witnesses from possible intimidation by the defendant - and the interests of the society - state secrets and executive privilege have not been defined. Neither have the courts considered how to prevent defense lawyers from abusing the benefits they acquire from the prosecutor's

60. See United States v. Jencks, 353 U.S. 657,669 (1957). "The practice of producing government documents to the trial judge for his determination of relevancy and materiality; without hearing the accused, is disapproved." Ibid. But see the Jencks Act, 18 U.S.C. $\$ 3500$ (1958).

61. Of course we do not mean to suggest that the courts should not be involved when a dispute arises between the prosecutor and the defense counsel. Once the courts set guidelines, however, these cases should be rare.

62. See text accompanying notes $38 \& 39$ supra. Cicenia v. Lagay, 357 U.S. 504, 510-11 (1958), and Leland v. Oregon, 343 U.S. 790, 801-02 (1952), have never been considered limitations on the suppression cases. In any event, both were decided before Brady $v$. Maryland, and lack strong precedential value.

63. The Note here assumes an honest prosecutor. Any mechanism for disclosure vould be ineffective if the prosecutor were dishonest. Problems of policing the prosecutor may arise, but they are beyond the scope of this Note.

64. See Traynor, supra note 1 , at 242 n.77.

65. See Commonwealth v. Stepper, 54 Lack Jur. 205 (Pa. C.P. 1952). "We would rather remove any obstacle to a fair trial, before the trial, rather than have it removed later and double the expense of difficult proceedings to the commonwealth." Id. at 212-13.

66. Since these suppression cases are based on the defendant's lack of knowledge about relevant evidence rights and duties arising out of them should not be made to depend too heavily on his making a request for information. See Barbee v. Warden, 331 F.2d 842, 845 (4th Cir. 1964); and United States ex rel. Mreers v. Wilkins, 326 F.2d 135, 137 (2d Cir. 1964). 
duty. Nor has the claim that the defense should be required to reveal its evidence been discussed adequately. ${ }^{67}$ All of these are hard questions, but their difficulty does not excuse the courts or the legislatures from finding the answers. ${ }^{\text {es }}$ The suppression cases articulate a constitutional principle which must now be effectuated.

67. But see Jones v. Superior Court, 58 Cal. 2d 56, 372 P.2d 919 (1962).

68. Guidance may be found in a close study of civil and criminal discovery mechanisms in federal and state jurisdictions. The experience in California might be particularly helpful. See Traynor, supra note 1, at 243-50. See also Louisell, silpra note 40; and Note, 60 YALE L.J. 626 (1951). 